\title{
Análise da qualidade da água do rio Traíras na Reserva Legado Verdes do Cerrado (LVC)
}

\section{Water quality analysis of Traíras river in the Legado Verdes do Cerrado (LVC) reserve}

Cássia Monalisa dos Santos Silva - Doutoranda em Geografia, pela Universidade de Brasília (UnB). Professora do Curso superior de tecnologia em Mineração pela Universidade Estadual de Goiás (UEG), Campus Norte/Unidade Universitária de Niquelândia. E-mail: cassia.silva@ueg.br

Wagner Sobrinho Rezende - Graduando do curso superior de Tecnologia em Mineração, pela Universidade Estadual de Goiás (UEG), Campus Norte/Unidade Universitária de Niquelândia. E-mail: wagnersobrinho23@gmail.com

Marcelo Alves da Silva Sales - Graduando do curso superior de Tecnologia em Mineração, pela Universidade Estadual de Goiás (UEG), Campus Norte/Unidade Universitária de Niquelândia. E-mail: marcelo.0410@hotmail.com

\section{Resumo}

Os rios são fontes de um dos recursos naturais indispensáveis aos seres vivos, tendo elevada importância cultural, socioeconômica, histórica nas cidades onde se localizam. O presente estudo objetivou avaliar os parâmetros físico-químicos da água do rio Traíras localizado na reserva particular de desenvolvimento sustentável Legado Verdes do Cerrado, na cidade de Niquelândia-GO, sendo este a principal fonte de abastecimento de água da população. $\mathrm{Na}$ presente pesquisa foram selecionados cinco pontos de coleta da água do rio Traíras para aferição das características físicoquímicas, tais como: $\mathrm{pH}$, turbidez, cor e sólidos totais dissolvidos. Os resultados das análises das quatro fases sazonais das coletas dos cinco pontos evidenciaram que as condições da água bruta do rio se encontram dentro dos limites permitidos pela resolução CONAMA nº 357/2005, apresentando caráter adequado de consumo, mesmo ocorrendo alterações ambientais irreversíveis nas adjacências do corpo hídrico. Assim, é importante a implementação do plano de gestão ambiental para minimizar futuros impactos.

\section{Palavra-chave}

Cidade de Niquelândia. Corpo Hídrico. Parâmetros Físico-Químicos. Alterações Ambientais.

\begin{abstract}
The rivers are indispensable natural resources for living beings, having the high cultural, socioeconomic, historical importance in the cities where they are located. This study aimed to evaluate the physicochemical parameters of the Traíras river located in the private reserve of sustainable development Legado Verdes do Cerrado, in the Niquelândia-GO city, which is the main source of water supply to the population. In the present research, five points of water collection from Traíras river were selected to measure the physical-chemical characteristics, such as $\mathrm{pH}$, turbidity, color, and total dissolved solids. The analysis result for the four seasonal phases of the five-point collections showed that the river raw water conditions are within the limits allowed by CONAMA 357/2005 presenting an adequate character of consumption, even if irreversible environmental changes occur near the water body. However, it is important to implement the environmental management plan to minimize future impacts.
\end{abstract}

\section{Keywords}

Niquelândia City. Water Body. PhysicalChemical Parameters. Environmental Changes. 


\section{INTRODUÇÃO}

A água é um recurso natural renovável e importante para a vida dos seres da Terra. Conforme Silva et al. (2015), a disponibilidade e o acesso à água são questões oriundas de questões políticas, tornando a água um recurso inerentemente relacionado com o balanço de poder entre os grupos sociais, independente da escala espacial. Segundo De Souza (2014), o uso da água pela sociedade visa atender às necessidades econômicas (agrícolas e industriais) e sociais. Contudo, essas formas de uso da água, quando realizadas inadequadamente, provocam alterações na qualidade da mesma, afetando os recursos hídricos e, por consequência, a sua utilização. A qualidade da água é de suma importância quando está direcionada ao abastecimento e consumo humano, pois é por meio dos padrões pré-definidos físico-química, biológica e legalmente que o consumo ou não da água de um corpo hídrico é determinado.

Diversas discussões dentro da comunidade científica quanto à disponibilidade hídrica e à utilização adequada destes recursos vêm sendo abordadas em diferentes áreas dos segmentos ambientais e sociais, seja dentro do viés da sustentabilidade, como também, do ponto de vista do planejamento e da gestão ambiental. Conforme Lima (2001), a disponibilidade hídrica mundial é estimada em $40.000 \mathrm{~km}^{3} /$ ano, e deste valor foi aferido que aproximadamente $10 \%$ dessa água são captados dos rios e destinados ao consumo humano. De todo o volume captado, foi estimado ainda que apenas 50\% dele são consumidos e os outros 50\% retornam ao corpo hídrico receptor, com uma qualidade inferior à que foi captada.

O Brasil é privilegiado em relação aos outros países em disponibilidade hídrica, possuindo cerca de $12 \%$ da água doce total do planeta. No entanto, este recurso natural é distribuído de forma desordenada, tendo concentrado aproximadamente $73 \%$ da água doce produzida no país na região Norte, que por sua vez possui 8,41\% da população total do Brasil (IBGE, 2019). De acordo com a Agência Nacional de Águas (ANA), o problema da escassez hídrica no Brasil tem como base tanto o crescimento exagerado quanto as demandas localizadas, considerando-se, também, a degradação dos recursos hídricos, o desmatamento e o uso de agrotóxicos utilizados em plantações de grãos de larga escala, como, por exemplo, a expansão do cultivo da soja transgênica (ANA, 2007).

Segundo Porto e Porto (2008), todas as áreas que apresentam atividades industriais, urbanas e agrícolas fazem parte de uma bacia hidrográfica. As consequências, ou seja, os impactos negativos sobre essas bacias hidrográficas são reflexos dos processos de ocupação do território. A ANA (2017) afirma que no Brasil são retirados para consumo de água aproximadamente $2.057,8 \mathrm{~m}^{3} / \mathrm{s}$ de rios, 
córregos, lagoas, lagos e reservatórios, sendo que 46,2\% vão para irrigação. Já a vazão média de consumo é de $1.081,3 \mathrm{~m}^{3} / \mathrm{s}$ e, deste total, $67,2 \%$ são consumidos pela irrigação. Para esta atividade econômica, o Brasil ainda tem um potencial de crescimento de 76 milhões de hectares, sobretudo na região Centro-Oeste do território nacional.

O estado de Goiás tem uma disponibilidade hídrica com vazão média estimada de $141 / \mathrm{s} / \mathrm{km}^{2}$ que dispõe de $39.185 \mathrm{~m}^{3} /$ ano/habitante, considerando $2.500 \mathrm{~m}^{3} /$ ano/habitante, volume suficiente para as atividades de uma pessoa (SILVA NETO et al., 2016). As principais utilizações das águas nestas bacias são destinadas ao abastecimento público, às irrigações, às atividades minerárias, aos distritos agroindustriais e às atividades de pisciculturas (SANTOS; PAIXÃO, 2003).

O norte de Goiás é uma das regiões mais bem abastecidas do estado, pois duas bacias hidrográficas importantes (Araguaia e Tocantins) compreendem essa área do estado. De acordo com o Ministério do Meio Ambiente (MMA) (BRASIL, 2006a), a bacia hidrográfica do Tocantins compreende 24,61\% da região norte do estado de Goiás e atende a grande demanda das necessidades hídricas dessa região, que apresenta uma baixa densidade demográfica devido ao pequeno desenvolvimento na parte norte-nordeste do estado.

No município de Niquelândia, localizado na mesorregião do Norte-Goiano, o setor industrial (notadamente o de extração mineral) e o abastecimento público são as maiores demandas de consumo de água doce da cidade, ressaltando que o setor agrícola vem se desenvolvendo desde o ano de 2016 após o fechamento da principal mineradora da cidade.

As práticas agrícolas fomentadas de forma irregular, vilipendiando a legislação ambiental, têm provocado acentuados impactos ambientais que levam à fragmentação do habitat e, algumas vezes, a estragos de caráter irreversível na maior biodiversidade savânica do mundo, o bioma Cerrado. Como consequências dessas ações negativas, os corpos hídricos que se encontram na região têm sido diretamente afetados devido aos processos de assoreamento, desmatamento, contaminações, mas também ao uso inadequado das suas águas para fins de atividades rurais.

O rio Traíras é a principal fonte de abastecimento de aproximadamente 46 mil habitantes do município de Niquelândia (IBGE, 2018). Tem suas duas nascentes compreendidas no interior da reserva particular de desenvolvimento sustentável Legado Verdes do Cerrado (LVC), onde algumas ações antrópicas, tais como o ecoturismo e as atividades relacionadas ao setor agrícola, vêm sendo desenvolvidas com o intuito de atender às necessidades da demanda econômica 
local, gerando diversas questões ambientais acerca do uso inadequado, dos danos ambientais e da qualidade da água do rio para consumo.

Nesse sentido, o presente estudo objetiva verificar a qualidade ambiental do corpo hídrico, de modo a investigar se a introdução das novas atividades agrícolas, principalmente a monocultura da soja transgênica e a pecuária que vem sendo expandida na reserva LVC, estão causando transformações na dinâmica natural dos ecossistemas, especialmente na qualidade ambiental da água bruta do rio Traíras, onde foram aferidos pontos de assoreamento relacionado à supressão da vegetação.

\section{POTENCIALIDADE HÍDRICA DO NORTE GOIANO}

Silva, Silva e Oliveira (2018) afirmam que a região Centro-Oeste do país é composta por várias bacias hidrográficas, possuindo características peculiares em relação à hidrografia, essencialmente em Goiás e no Distrito Federal. Destacase que nessas áreas nascem drenagens alimentadoras onde o estado desfruta de algumas dessas bacias, sendo elas uma pequena porção da bacia do São Francisco, a bacia do Tocantins/Araguaia e do Paraná. Essa hidrografia possui também o lago de Cana Brava, que é abastecido pelo lago Serra da Mesa (GOIÁS, 2006).

A bacia do Tocantins/Araguaia é a mais importante para a região norte do estado de Goiás, pois grande parte dela se localiza na região Centro-Oeste, desde as nascentes de ambos os rios Araguaia e Tocantins até a confluência, para a jusante, adentrando na região Norte do país e finalmente chegando até a foz, no oceano Atlântico. Em sua totalidade a bacia do Tocantins/Araguaia compreende uma superfície de $918.273 \mathrm{~km}^{2}$, ou seja, aproximadamente $11 \%$ do território nacional, em que 26,8\% corresponde ao estado de Goiás e 34,2\% ao estado do Tocantins (BRASIL, 2006a). De acordo com dados da ANA e do MMA, a disponibilidade hídrica da bacia Tocantins/Araguaia é de $13.624 \mathrm{~m}^{3} / \mathrm{s}$ de vazão média, o que equivale a 9,6\% do total do país, uma vez que sua vazão específica média é de 14,84 L/s $/ \mathrm{km}^{2}$, considerando sua área total (BRASIL, 2006a; ANA, 2007).

A região de Niquelândia se enquadra na bacia do Tocantins, que é formada a partir da junção dos rios Maranhão e Tocantinzinho, e abrange os rios das Almas, dos Patos, Verde, Preto, Paraná e Traíras, sendo este último o nosso objeto de estudo.

A hidrografia do município niquelandense é abarcada por um rio principal, o Tocantins. O mesmo é formado por dois rios importantes em seus limites naturais: o rio Maranhão, que recebeu esse nome devido ao período colonial, pois os bandeirantes navegaram por ele chegando até o estado do Maranhão; e 
o segundo é o rio Tocantinzinho, que recebeu esse nome em razão aos índios Tucantins. Existem outros rios importantes que compõem a bacia do Tocantins que, no entanto, não foram explorados cientificamente, são eles: o rio Traíras e o rio Bagagem (BERTRAN, 1985, 1998). Ambos os rios, Traíras e Bagagem, são volumosos e percorrem serras com altitudes de 1.400 metros. O rio Traíras constitui umas das vertentes que abastece o quinto maior lago do Brasil, o lago artificial da usina Serra da Mesa, que compreende cerca de $1.784 \mathrm{~km}^{2}$ da área inundada, com volume de água de aproximadamente 54,4 bilhões de $\mathrm{m}^{3}$ (RODARTE et al., 2018).

A ausência de informações sobre o rio Traíras dificulta o conhecimento sobre seus aportes de recursos, os impactos sofridos e sua utilidade. Como mencionou Bertran (1985), desde o processo de fundação do município de Niquelândia, o rio vem sendo utilizado por uma diversidade de ações impactantes, tais como a exploração do ouro durante o período colonial, a pesca predatória, as atividades de lazer irregular e a utilização das suas águas para finalidades de consumo doméstico, pois o mesmo é a única fonte de abastecimento de água da cidade niquelandense.

O rio Traíras apresenta duas nascentes, sendo uma perene e outra permanente. O primeiro mapeamento do rio foi iniciado ainda no primeiro semestre de 2017, identificando as duas nascentes e suas condições atuais de preservação. Ambas as nascentes afloram dentro da reserva LVC e o curso do rio chega a perfazer $92 \mathrm{~km}$ de extensão dentro da reserva. Ressalta-se que em alguns pontos do rio é possível perceber processos erosivos e de supressão da mata ciliar, sobretudo nas áreas afetadas pela atividade agrícola, especialmente da inserção da monocultura de soja transgênica (PEREIRA, 2017). Atualmente, a reserva dispõe de um total de 5 mil hectares destinados à abrangência das atividades agrícolas; área essa onde se faz necessária a realização de um zoneamento ecológico econômico eficiente, a fim de equilibrar os futuros impactos ao bioma Cerrado e, consequentemente, aos corpos hídricos que fazem parte do cenário da reserva. $\mathrm{Na}$ área externa à reserva, por sua vez, existem diversas outras atividades do segmento agrícola (soja, milho, criação de porcos e gados) além das atividades de lazer.

O Plano Nacional dos Recursos Hídricos (PNRH) no âmbito da Lei no 9.433/1997 e da Resolução do CONAMA n 357/2005 (BRASIL, 2005), foi criado como meta para manter a qualidade da água de cada rio, trecho de rio, lago e águas subterrâneas contidas em aquíferos. Silva, Silva e Oliveira (2018) afirmam que essas metas devem ser mantidas, cumpridas e alcançadas no intuito de planejar de forma consistente a qualidade do fluido e assegurar que suas destinações sejam explícitas. No entanto, à água que necessitar de maiores exigências em 
sua qualidade, deve-se requerer maior minuciosidade no tratamento. Já a água que solicitar de menos requisitos de qualidade serão mais flexíveis perante a sua legislação apropriada.

Os recursos hídricos são regidos por leis e decretos que estabelecem diretrizes para sua utilização, dentre elas a Resolução do CONAMA nº 357/2005 sendo a principal responsável pela classificação desses recursos. A Resolução n⿳o $357 / 2005$ define como água doce aquela que possui salinidade inferior a 0,05\%. A classificação dos corpos d'água tem como princípio estabelecer valores para o uso desse bem natural, do qual o Instituto Nacional de Metrologia, Normalização e Qualidade Industrial (INMETRO) é o responsável por avaliar a qualidade dos corpos d'água. Todavia, sua classificação de uso foi regulamentada pela resolução $\mathrm{n}^{\mathrm{o}}$ 12, de julho de 2000, e sancionada pelo Conselho Nacional de Recursos Hídricos (CNRH).

As águas doces são classificadas em 5 tipos, conforme citado no artigo $4^{\circ}$ da Resolução do CONAMA no 357/2005, sendo divididas nas classes 1, 2, 3, 4 e classes especiais, de acordo com o indicado no Quadro 1. Neste estudo, o rio Traíras se enquadra na classe 2 , pois o mesmo fornece água para o abastecimento público da cidade niquelandense e necessita apenas de tratamento convencional. Ademais, no decorrer do seu curso, é utilizado para agricultura de grande porte e de subsistência por pequenos produtores (irrigação de lavouras, bebedouros para gado, pesca) e até mesmo para o consumo humano em locais onde não há disponibilidade de água tratada.

Quadro 1 - Classificação dos rios de acordo com a Resolução do CONAMA $\mathrm{n}$ 을 $357 / 2005$

\begin{tabular}{|c|l|}
\hline CLASSES & \multicolumn{1}{c|}{ DESTINAÇÃO } \\
\hline ESPECIAL & $\begin{array}{l}\text { Consumo humano, com desinfecção; preservação do equilíbrio natural } \\
\text { das comunidades aquáticas; preservação dos ambientes aquáticos em } \\
\text { unidades de conservação de proteção integral. }\end{array}$ \\
\hline $\begin{array}{c}\text { CLASSE } \\
\text { I }\end{array}$ & $\begin{array}{l}\text { Consumo humano; proteção das comunidades aquáticas; à recreação de } \\
\text { contato primário; à irrigação de hortaliças que são consumidas cruas e } \\
\text { de frutas; à proteção das comunidades aquáticas em Terras Indígenas. }\end{array}$ \\
\hline $\begin{array}{c}\text { CLASSE } \\
\text { II }\end{array}$ & $\begin{array}{l}\text { Consumo humano; à proteção das comunidades aquáticas; à recreação } \\
\text { de contato primário; à irrigação de hortaliças, plantas frutíferas e de } \\
\text { parques, jardins, campos de esporte e lazer, e à aquicultura e à atividade } \\
\text { de pesca. }\end{array}$ \\
\hline $\begin{array}{c}\text { CLASSE } \\
\text { III }\end{array}$ & $\begin{array}{l}\text { Consumo humano, após tratamento convencional ou avançado; à } \\
\text { irrigação de culturas arbóreas, cerealíferas e forrageiras; à pesca amadora; } \\
\text { à recreação de contato secundário; e à dessedentação de animais. }\end{array}$ \\
\hline CLASSE IV & à navegação; e à harmonia paisagística. \\
\hline
\end{tabular}

Fonte: Cunha et al. (2013). 


\section{RESERVA PARTICULAR DE DESENVOLVIMENTO SUSTENTÁVEL LEGADO VERDES DO CERRADO (LVC)}

A Reserva Particular de Desenvolvimento Sustentável Legado Verdes do Cerrado (LVC) localiza-se na região Norte do estado de Goiás, no município de Niquelândia, e foi instituída no ano de 2017 após a assinatura de um protocolo de intenções entre uma antiga mineradora da cidade e o governo do estado de Goiás. A reserva LVC apresenta $115 \mathrm{~km}$ de perímetro com 80\% do Cerrado preservado e algumas áreas em estado de conservação desde 1947, ao todo são 32 mil hectares com uma rica biodiversidade de flora e fauna nativas, além de uma alta potencialidade hídrica, contando com três (3) rios que nascem dentro da reserva (São Bento, do Peixe e Traíras), além de 11 córregos. A reserva está dividida em duas propriedades (Mapa 1), uma denominada de fazenda Engenho (27 mil hectares) e a outra de Serra Negra (5 mil hectares).

Mapa 1 - Localização da Reserva Legado Verdes do Cerrado (LVC)

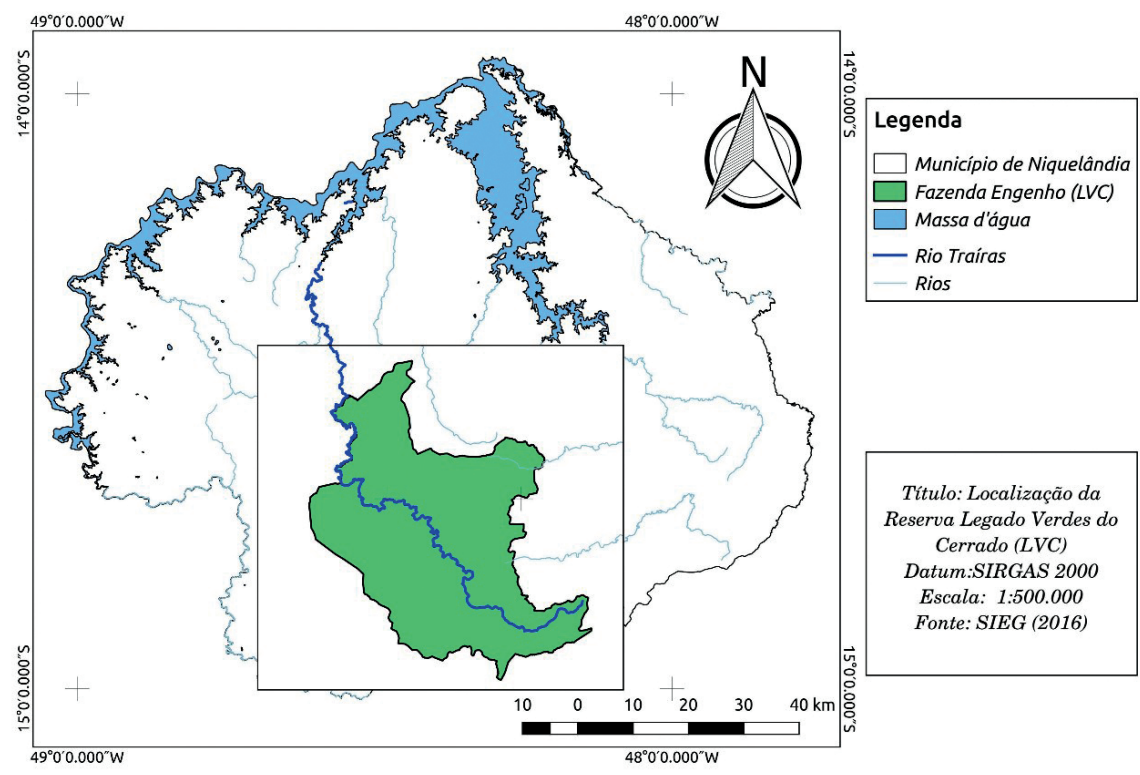

Fonte: Autores (2019).

A fazenda Engenho engloba a maior parte da reserva do LVC e, atualmente, vem passando por transformações sérias e de altas responsabilidades no que diz respeito ao planejamento ambiental em sua gestão atual, tais como: a criação do viveiro de mudas nativas com uma produção, em 2018, de 80 mil mudas para reflorestamento de áreas de preservação permanentes (APP) e produção de 
frutos do Cerrado, a promoção de atividades de ecoturismo para o público local e das regiões adjacentes; a realização de pesquisas e desenvolvimento científico, envolvendo diversas universidades do território nacional. Além disso, algumas propostas de atividades convencionais relacionadas à agricultura em uma área de 1800 hectares já foram introduzidas, como, por exemplo, a produção de mel em larga escala; o cultivo de soja transgênica, com a média de produção, para o ano de 2018, de aproximadamente 55 sacas por hectare, e de milho safrinha, com a média de 80 sacas por hectare. Tais atividades vêm sendo planejadas e desenvolvidas, com intenção de fornecer apoio às demandas socioeconômicas locais, pois o município de Niquelândia tinha sua total dependência econômica durante os últimos 40 anos proveniente da atividade minerária - a extração do minério de níquel (Ni) e ferro $(\mathrm{Fe})$.

A Serra Negra, que compreende a menor parte da LVC, abriga uma imensa biodiversidade de animais do cerrado nativo. Esses 5 mil hectares comportam apenas atividades de pesquisa, devido a sua localização geográfica e geomorfológica e a quantidade de animais selvagens e peçonhentos. Neste local, biólogos, ecólogos e demais cientistas de variadas instituições públicas do estado de Goiás e de todo território nacional vêm desenvolvendo uma gama de pesquisas científicas com financiamento privado e público.

O rio Traíras está compreendido na fazenda Engenho, que possui sua geologia localizada dentro de um corpo de rochas do complexo máficoultramáfico com idade geológica que segue do arqueano à proterozóica inferior. Uma característica marcante do complexo máfico-ultramáfico em Niquelândia é que, em sua divisão, o mesmo está associado à sequência vulcanossedimentar Coitezeiro ao leste, e pela zona de cisalhamento do rio Traíras ao oeste. A zona de cisalhamento do rio Traíras faz parte do limite do complexo niquelandense, que apresenta deformações dúcteis e tem como características predominantes as rochas milonitos que se recristalizam virando blastom ilonitos (BROD; JOST, 1991).

A vegetação da região é formada pelo bioma savana tropical estacional (peino pirobioma), ou seja, o Cerrado. O Cerrado tem seu ápice de distribuição na parte do Planalto Central do Brasil, com suas periferias mais ao sul abrangendo até o estado do Paraná, em forma de resquícios isolados. Na parte norte atinge Roraima, na direção nordeste abarca a região dos tabuleiros, chapadas e baixos planaltos e na direção oeste, chegando até a Bolívia, na região de Beni (COUTINHO, 2016).

Ainda conforme Coutinho (2016), o clima predominante no bioma Cerrado é o tropical estacional com temperaturas médias mensais de $22^{\circ} \mathrm{C}$ a $26^{\circ} \mathrm{C}$, dependendo da região. $\mathrm{Na}$ cidade de Niquelândia a sazonalidade 
anual pluviométrica tem características de comportamento de estiagem nos períodos de maio a setembro, e enxurradas nos períodos de outubro a março, atingindo regime pluviométrico anual de $1.713 \mathrm{~mm}$, com temperatura média anual de $25^{\circ} \mathrm{C}$ (INMET, 2016).

\section{COLETA DE DADOS E ANÁlISE DA ÁGUA DO RIO TRAÍRAS, NIQUELÂNDIA, GOIÁS}

Para a elaboração das coletas foram realizadas as demarcações com localizações geográficas dos 5 pontos, como observado na Figura 1 (a) e (b) e estabelecido um plano para 4 (quatro) momentos de coleta dentro da reserva LVC, sendo duas coletas em período de seca (24.08.2018) e (21.09.2018) e duas coletas em período de chuvoso (26.10.2018) e (23.11.2018), perfazendo um curto período de sazonalidade, mas que coincidem com os dois períodos climáticos definidos na região do Cerrado e que foram acompanhados pelas estação meteorológica automática do INMET, que compreende a mesorregião do Norte Goiano.

Figura 1 - (a) Pontos de coleta AM-02 com demarcações geográficas e (b) Pontos de coleta AM-03 com demarcações geográficas
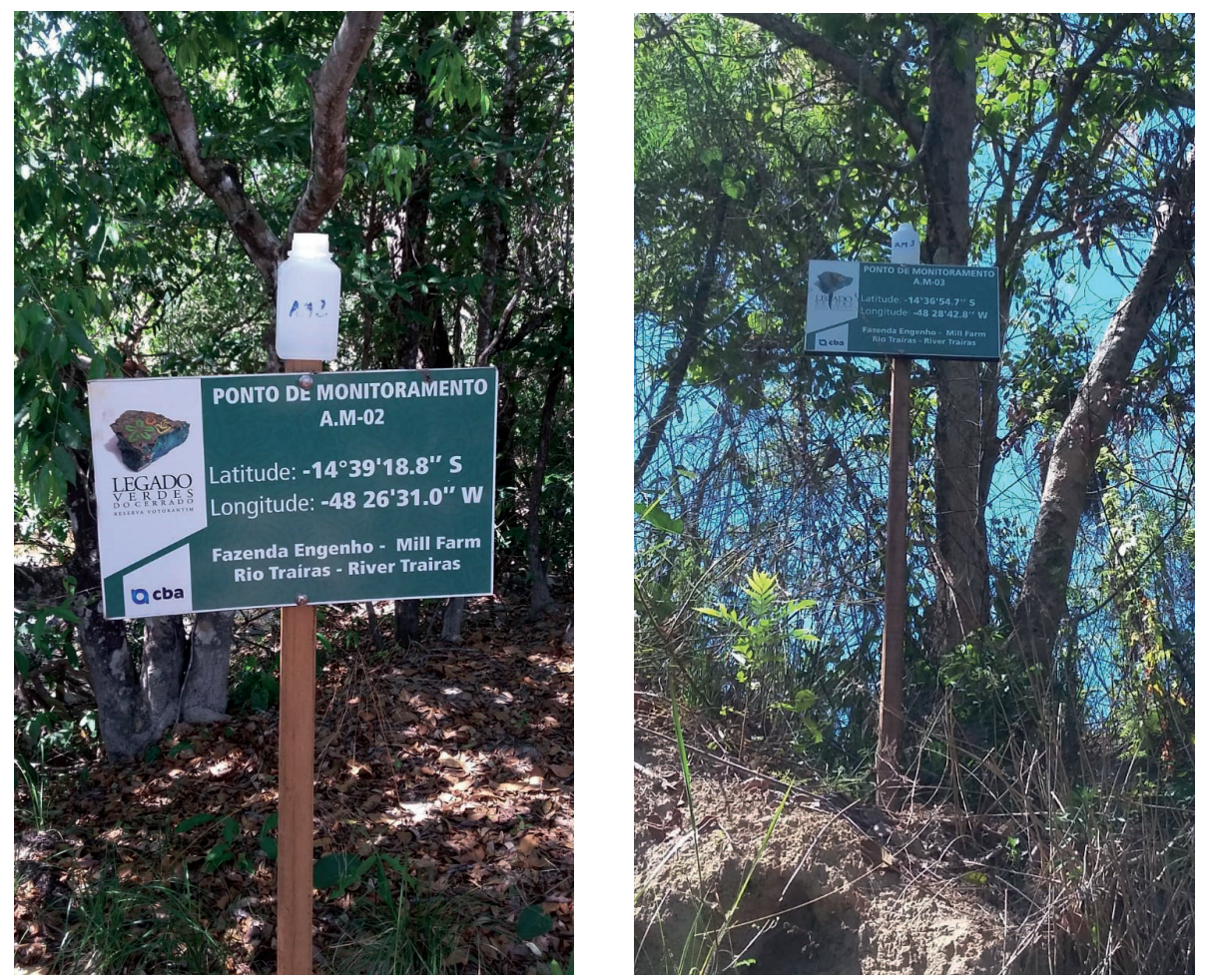

Fonte: Autores (2019). 
Segundo Silva, Silva e Oliveira (2018), a área apresentada no Mapa 2, indica os pontos de coleta das amostras, os quais foram determinados visando representar os locais de maior probabilidade de influência antrópica em pontos onde o corpo hídrico em estudo banha a reserva Legado Verdes do Cerrado em suas duas margens. Nestes pontos foram coletadas as amostras AM-01; 02 e 03,

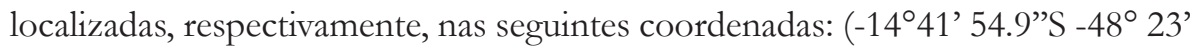

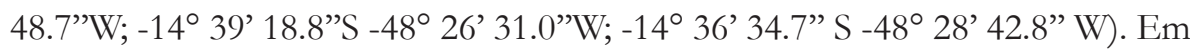
locais que uma das margens do corpo hídrico é de propriedade da reserva e na outra margem é de posse de proprietários terceiros, foram coletadas as amostras AM-04 (-14 34' 27.9"S -48 31' 56.0”W) e AM-05 (-14 32' 18.4” S -48 32' $19.8^{\prime \prime}$ ). Essa distribuição dos pontos dentro dos perímetros da reserva LVC podem ser observados no Mapa 2.

Mapa 2 - Pontos de coleta do rio Traíras, fazenda Engenho

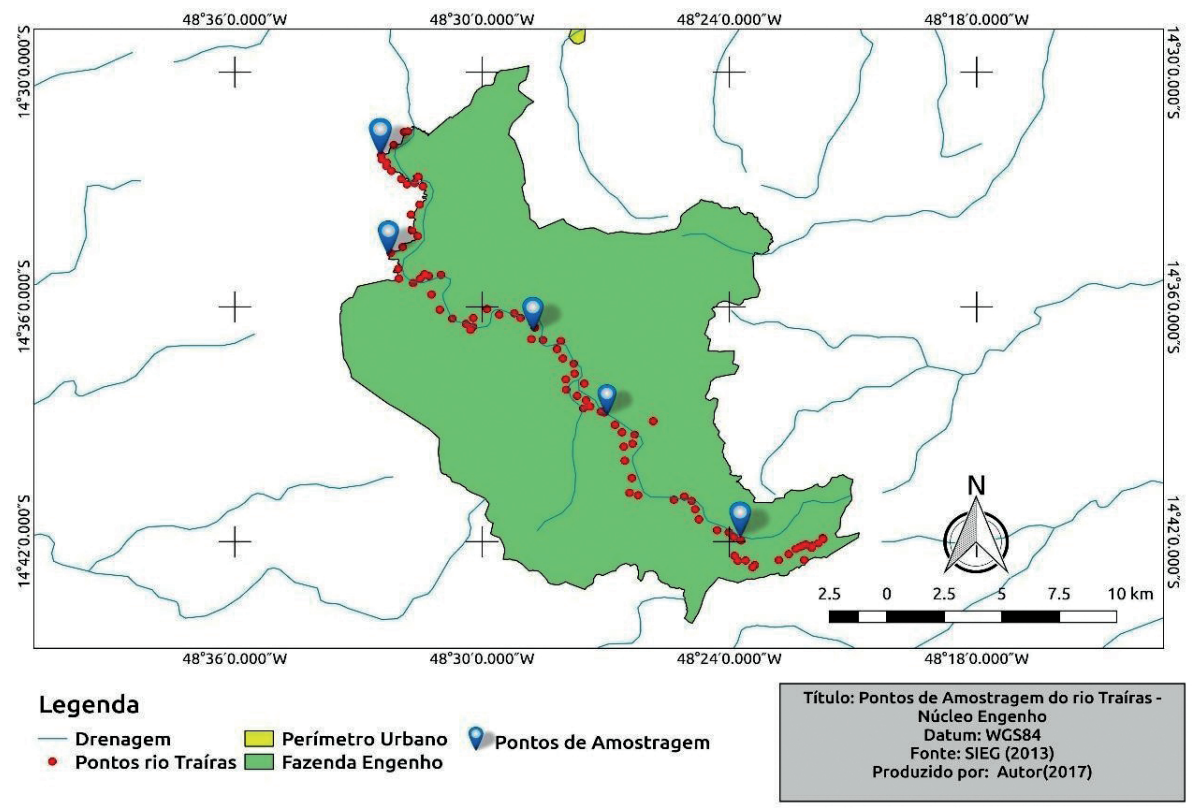

Fonte: Silva, Silva e Oliveira (2018).

Para a realização das coletas foram utilizados frascos novos e específicos, conforme a Figura 2 (a) e (b), seguindo os padrões fornecidos pelo manual de amostragem da EMBRAPA (PARRON; MUNIZ; PEREIRA, 2011), que indica a necessidade de esterilização do material antes de receber as amostras. 
Figura 2 - (a) Coleta da amostra de água em ponto demarcado (b) Frascos de coleta para armazenamento das amostras e caixa térmica para conservação
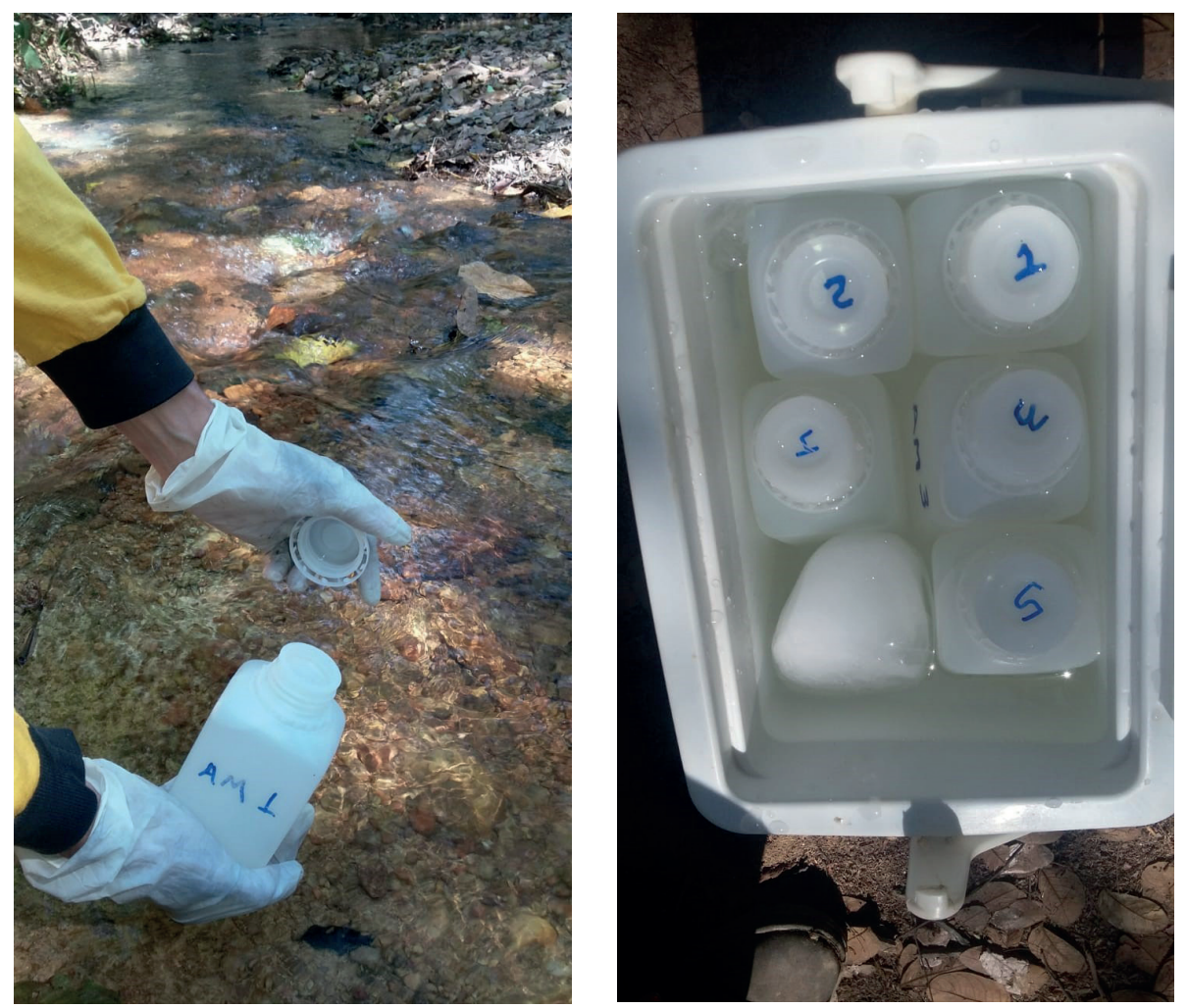

Fonte: Autores (2019).

As amostras foram coletadas e acondicionadas em uma caixa térmica com gelo em condição ideal de temperatura para a realização das análises dentro de um prazo de 24 horas em laboratório.

As duas primeiras coletas (24.08.2018) e (21.09.2018) ocorreram após um período de estiagem, no qual a região já havia passado por aproximadamente 02 meses sem precipitação. As duas últimas coletas (26.10.2018) e (23.11.2018) ocorreram no momento inicial da estação úmida, marcada por chuvas intensas na região, como pode ser observado na Figura 3, que evidencia a distribuição das chuvas no período de coleta dos dados. 
Figura 3 - Distribuição da precipitação na mesorregião do Norte Goiano

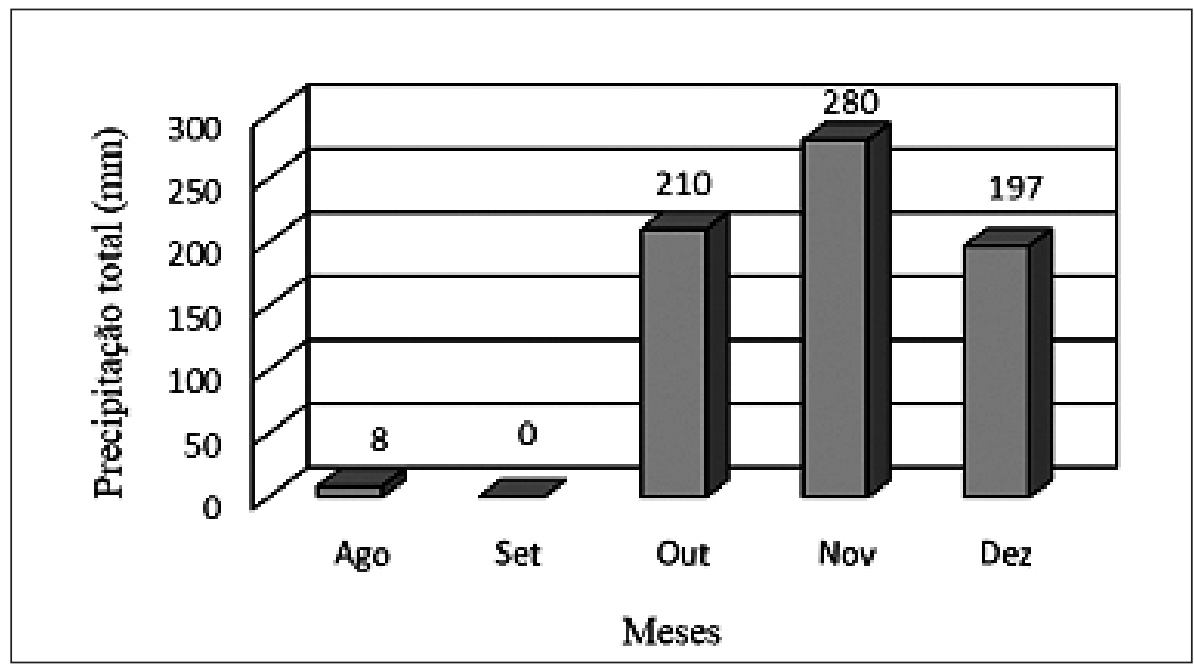

Fonte: INMET (2018).

As determinações analíticas foram realizadas em triplicata no laboratório de análise físico-química da Companhia Brasileira de Alumínio (CBA). O primeiro passo foi a calibração dos aparelhos para melhor confiabilidade dos valores liberados. As variáveis analisadas foram: potencial hidrogenionico $(\mathrm{pH})$; turbidez; e cor e sólidos totais dissolvidos. Após as análises, foram extraídos os resultados das cinco fases para os quatro pontos de coleta demarcados e comparados com o Valor Máximo Permitido (VMP) da Resolução do CONAMA nº 357/2005 da classe 2, como referenciado na Tabela 1.

Tabela 1 - Valores máximo e mínimo permitidos para análises dos parâmetros físico-químicos de água de rios (classe 2) de acordo com a Resolução do CONAMA nº 357/2005

\begin{tabular}{c|c|c|c}
\hline Parâmetros & Método & VMP & Unidade de medida \\
\hline $\mathrm{pH}$ & Indicador & $6,0-9,0$ & um. pH \\
\hline Cor & Comparação visual & 75 & (Pt Co) \\
\hline $\begin{array}{c}\text { Turbidez } \\
\begin{array}{c}\text { Sólidos totais dissolvidos } \\
\text { (STD) }\end{array}\end{array}$ & Indicador & 500 & $\begin{array}{c}\text { NTU } \\
\text { (unidades nefelométrica) }\end{array}$ \\
\hline
\end{tabular}

Fonte: Brasil (2006a). 


\section{RESULTADOS E DISCUSSÕES}

Os resultados obtidos das análises físico-químicas realizadas por triplicata podem ser observados de modo geral na Tabela 2 e nos gráficos a seguir, sendo possível compará-los aos valores máximos permitidos pela Resolução do CONAMA nํㅜ 357/2005, sugerindo que a água do rio Traíras nos pontos aferidos encontra-se dentro das conformidades exigidas pela legislação. Ressaltase a necessidade de considerar que o material em estudo se trata da água bruta do rio Traíras, o qual se enquadra na classe 2 da referida resolução.

Tabela 2 - Resultados dos parâmetros físico-químicos dos 5 pontos em dois períodos climáticos no ano de 2018

\begin{tabular}{c|c|c|c|c|c|c}
\hline Parâmetros & VMP & AM01 & AM02 & AM03 & AM04 & AM05 \\
\hline \multicolumn{6}{c}{ Período seco } \\
\hline pH & 9 & 7,54 & 7,74 & 7,85 & 7,77 & 7,93 \\
\hline Cor & 75 & 16,2 & 17,3 & 17,7 & 16 & 16 \\
\hline Turbidez & 100 & 0,85 & 1,06 & 0,64 & 0,85 & 0,96 \\
\hline STD & 500 & 100,9 & 97,6 & 90,6 & 136,4 & 156,4 \\
\hline \multicolumn{7}{|c|}{ Período seco } \\
\hline pH & 9 & 7,67 & 7,9 & 8,03 & 8,04 & 8,17 \\
\hline Cor & 75 & 18,4 & 17,9 & 16,6 & 15 & 13,5 \\
\hline Turbidez & 100 & 1,08 & 0,88 & 0,47 & 0,55 & 0,44 \\
\hline STD & 500 & 141,9 & 155,3 & 181,9 & 226,6 & 235,8 \\
\hline \multicolumn{7}{|c|}{ Período úmido } \\
\hline pH & 9 & 7,53 & 7,61 & 7,58 & 7,36 & 7,45 \\
\hline Cor & 75 & 24,2 & 36 & 102 & 185 & 136 \\
\hline Turbidez & 100 & 3,5 & 15,1 & 79 & 264 & 125 \\
\hline STD & 500 & 83,4 & 99 & 82,8 & 103,8 & 115,4 \\
\hline Turbidez & 100 & 2,23 & 6,72 & 11,18 & 22,9 & 125 \\
\hline STD & 500 & 65,2 & 83,4 & 47,1 & 48,1 & 46 \\
\hline pH & 9 & 8,1 & 8 & 8,15 & 7,91 & 8,22 \\
\hline Cor & 75 & 21,8 & 35,9 & 36 & 63,3 & 44,1 \\
\hline STríodo úmido \\
\hline Aut
\end{tabular}

Fonte: Autores (2019).

As análises das amostras do Gráfico 1 (a) para a variável $\mathrm{pH}$ no primeiro momento do período seco das coletas apresentaram-se em consonância com os parâmetros estabelecidos pela Resolução do CONAMA n 357/2005, mostrando 
que o ponto AM-01 em 24.08.2018 apresentou o menor indicador de $\mathrm{pH}$, em torno de 7,54, e AM - 05 com indicador de 7,93. Ainda assim, esses indicadores do Gráfico 1 (a) são menores que os coletados e analisados no ano de 2017 por Silva, Silva e Oliveira (2018) no período seco.

Maier (1987) afirma que a leve diminuição do $\mathrm{pH}$ pode estar relacionada ao aumento no teor de matéria orgânica, levando ao consequente declínio da quantidade de oxigênio dissolvido em disponibilidade no corpo d'água. Dento do mesmo contexto, Esteves (1998) afirma que o $\mathrm{pH}$ pode ser considerado uma das variáveis ambientais mais relevantes e, concomitantemente, uma das mais difíceis de se interpretar em função do grande número de fatores que podem influenciá-lo, haja vista que é influenciado pela concentração de íons $\mathrm{H}+$ oriundos da ionização do ácido carbônico que ocasionam valores baixos de $\mathrm{pH}$, gerando consequentemente um aumento na concentração hidrogeniônica e das reações de íons carbonato e bicarbonatos com a água, elevando valores de $\mathrm{pH}$ para a faixa alcalina que aumentam a concentração hidroxiliônica.

No Gráfico 1 (b), para 21.09.2018, o ponto AM-01 apresentou indicador um pouco mais elevado (em torno de 7,67), enquanto que o AM-05 teve indicador de 8,17. Tal aumento pode ser explicado pelo acréscimo do número de dias sem chuvas na região, pois características levemente ácidas são tendenciadas em período chuvoso (PAULA et al., 2013).

Gráfico 1 - Resultados das análises físico-químicas para variável potencial hidrogeniônico (pH) no período seco (a) (24.08.2018) e (b) (21.09.2018)

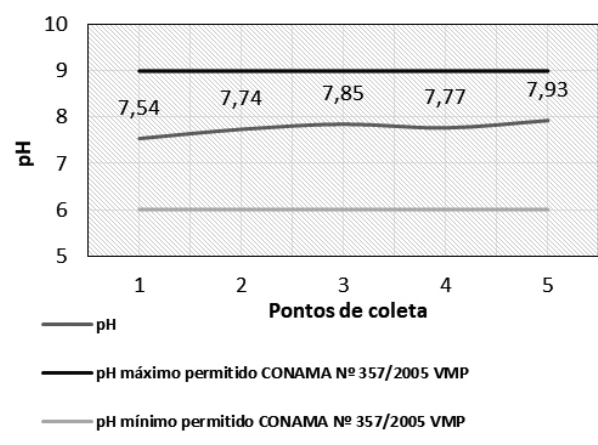

(a)

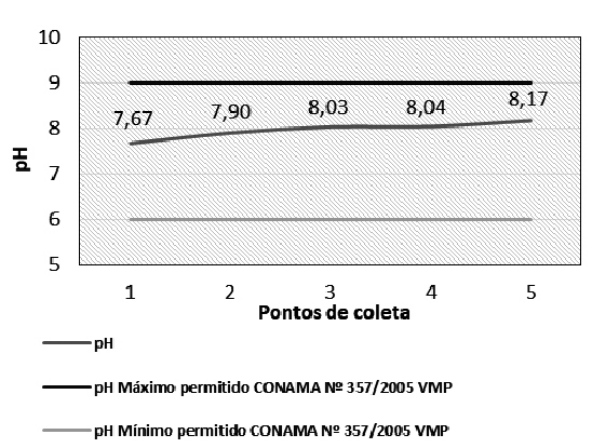

(b)

Fonte: Autores (2019).

$\mathrm{O}$ ano de 2018 teve um curto período de estiagem, e fenômenos como El Niño não foram intensos de acordo com o INMET (2018). Geralmente, em anos intensos do fenômeno El Nino, o quadro de seca se intensifica na região Centro- 
Norte do Brasil. Similaridades dos efeitos da atuação deste fenômeno ocorreram no ano de 2017, quando este período foi marcado por longos períodos sem chuvas na região chegando a registrar 120 dias (SILVA; SILVA; OLIVEIRA, 2018).

A variável cor para o período seco pode ser observada no Gráfico 2 (a) e 2 (b). Nota-se que os menores valores para 24.08.2018 ocorrem na AM-04 e AM-05 com valores em torno de 16,0 (Pt Co)/1 e o valor mais expressivo foi registrado no ponto AM-03 na grandeza de 17,7 (Pt Co)/1. O parâmetro cor fornece evidências de contaminação, como a presença de sólidos dissolvidos em suspensão ou material em estado coloidal (orgânicos e/ou inorgânicos) (SCORSAFAVA et al., 2010).

O resultado da amostra de 21.09.2018 observado no Gráfico 2 (b), apresentou baixos valores. O ponto AM-05 nas bordas da reserva LVC apresentou valor aproximado de 13,5 (Pt Co)/1, enquanto que nas proximidades da nascente os valores da variável cor mantiveram em torno de 18,4 (Pt Co)/l. Ressalta-se que os baixos valores nas diferentes amostras têm relação direta com a diminuição da presença de materiais dissolvidos e em suspensão na água ao longo do curso do rio. Em ambos os casos foi observado que as nascentes estavam com maiores valores da presença de material em suspensão neste período, isso pode ser explicado pela crescente quantidade de material orgânico em decomposição, uma vez que a nascente encontra-se em estado preservado. Assim, a variável cor em ambos os dias do período seco esteve dentro dos padrões estabelecidos pela Resolução do CONAMA no 357/2005, em que o limite aceitável é de 75 (Pt Co)/1.

Gráfico 2 - Resultados das análises físico-químicas para a variável cor (Pt Co)/1 no período seco (a) (24.08.2018) e (b) (21.09.2018)

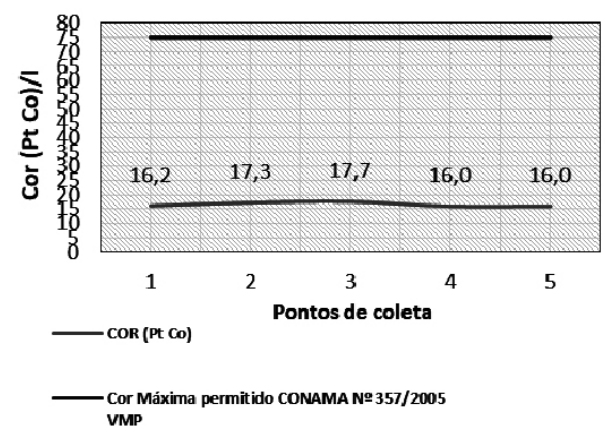

(a)

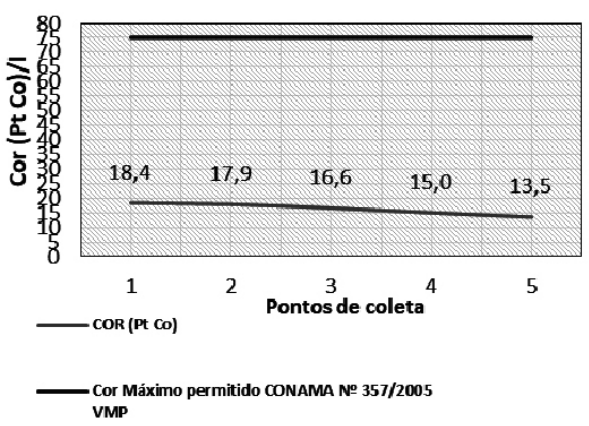

(b)

Fonte: Autores (2019). 
A variável turbidez observada no Gráfico 3 (a) e (b) é respectivamente do período seco, dos dias 24.08.2018 e 21.09.2018. No Gráfico 3 (a), percebe-se um comportamento relativamente constante durante todo o período analisado, sendo o valor menos expressivo em torno de 0,64 (NTU) no ponto de coleta AM-03 e o mais expressivo na ordem de 1,06 unidades nefelométrica (NTU), no ponto AM-02. O Gráfico 3 (b) mostra que comportamento semelhante foi apresentado no ponto AM-05, registrando o menor valor com 0,44 (NTU), enquanto que o ponto AM-01 apresentou o maior valor em torno de 1,06 (NTU). Correia (2008), em seu estudo no rio São Francisco, apresentou resultados semelhantes ao presente trabalho, com média de 1,8 NTU para o período seco.

Gráfico 3 - Resultados das análises físico-químicas para a variável turbidez (NTU) no período seco (a) (24.08.2018) e (b) (21.09.2018)

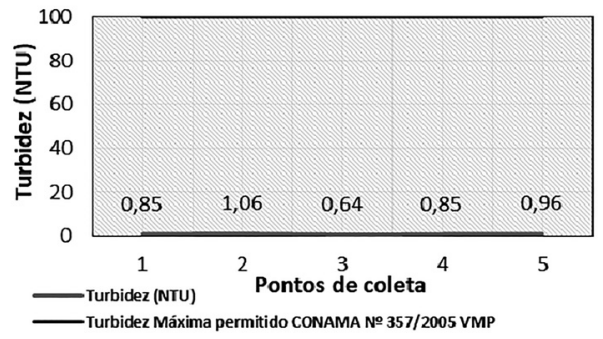

(a)

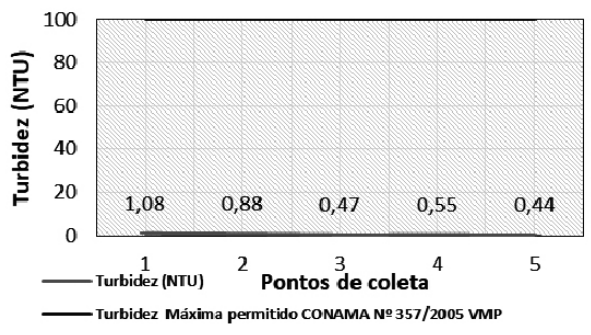

(b)

Fonte: Autores (2019).

Percebe-se que os baixos valores da variável turbidez sofrem influência da ausência de precipitação, que não favorece o movimento de partículas sólidas lixiviadas das áreas adjacentes para o corpo hídrico; fato que proporciona menores concentrações de materiais suspensos e diminui os riscos de contaminação e aumentando a qualidade ambiental da água.

O Gráfico 4 (a) e (b) apresenta os resultados das análises das amostras de sólidos totais dissolvidos (STD) coletadas nos 5 pontos ao longo do rio Traíras na reserva LVC para o período seco. Segundo Piratoba et al. (2017), os STD incluem todos os sais e componentes não iônicos. Os processos de intemperismo geram produtos que são encontrados nos corpos da água na forma iônica, sendo estes os principais constituintes dos STD. Observa-se no Gráfico 4 (a) que o ponto com a menor concentração de STD foi AM-03 com 90,6 ppm, enquanto que a menor concentração encontrada está no ponto AM-05 com 156,4 ppm, ou seja, de acordo com análise físico-química, essas amostras do dia 24.08.2018 estão abaixo dos padrões estabelecidos pela resolução do CONAMA 357/2005, que limita a concentração de STD em 500,0 ppm. 
A concentração de STD observada no Gráfico 4 (b) indica que a menor concentração ocorreu na AM-01, nas proximidades das nascentes, com valor de 141,9 ppm, e a maior concentração ocorre na AM-05, com valor de 235,8 ppm. Assim, nota-se um aumento no aporte de material alóctone concentrado nos pontos de coleta mais afastadas das nascentes. Isso pode ser explicado provavelmente pelas atividades antrópicas que são desenvolvidas nessas áreas, tais como a inserção de monoculturas e as atividades agropecuárias (criação de suínos e bovinos).

No entanto, as amostras tiveram comportamento abaixo do padrão estabelecido pela Resolução do CONAMA nº 357/2005. Silva, Silva e Oliveira (2018) explicam que a baixa concentração de STD no Gráfico 4 (a) e (b) pode ser compreendida pela ausência da precipitação no período de coleta das amostras. Além do mais, com as atividades antrópicas que têm sido desenvolvidas na reserva e em suas adjacências, em longo prazo, esses valores podem sofrer alterações mais significativas, mesmo que em períodos secos, pois com facilidade ultrapassarão os limites estabelecidos pela resolução aplicada para o corpo hídrico em estudo.

Gráfico 4 - Resultados das análises físico-químicas para a variável sólidos totais dissolvidos no período seco (a) (24.08.2018) e (b) (21.09.2018)

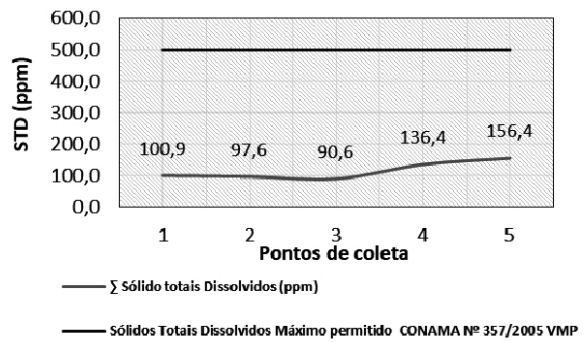

(a)

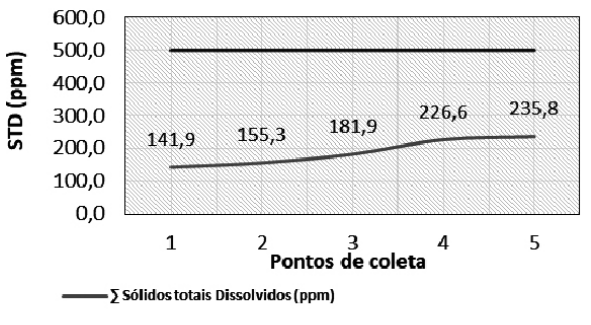

(b)

Fonte: Autores (2019).

Os resultados apresentados no Gráfico 5 (a) e (b) são ambos do período úmido, respectivamente dos dias 26.10.2018 e 23.11.2018, para a variável potencial de hidrogênio $(\mathrm{pH})$. O pH é um dos parâmetros mais comumente avaliados nos estudos de qualidade da água, especialmente quando se trata de água potável (BRASIL, 2006b), e pode ser influenciado por diversos fatores naturais e antropogênicos. Quando por fatores naturais, sua alteração pode ser influenciada pela dissolução de rochas, absorção de gases atmosféricos, oxidação da matéria orgânica e fotossíntese, mas quando por fatores antropogênicos, é pelo despejo de esgotos domésticos e industriais, devido à oxidação da matéria orgânica e à lavagem ácida de tanques, respectivamente (VON SPERLING, 2005). 
Observa-se que no Gráfico 5 (a) o pH tem valores com indicadores neutros a levemente alcalino, tendo seu menor valor na AM-04, com o indicador de 7,36, e maior valor na AM-02, com indicador de 7,61. Já o Gráfico 5 (b), do dia 23.11.2018, corresponde aos resultados da segunda etapa das coletas do período úmido. A AM-04 foi o ponto com o menor indicador, em torno de 7,91, valores semelhantes ao encontrado no período seco no Gráfico 1 (a) e (b). Já o ponto AM05 obteve o maior indicador, registrando 8,22. Nota-se que nesta segunda etapa as amostras tiveram resultados levemente alcalinos, devido a fatores naturais, mas ainda sim dentro dos parâmetros estabelecidos pela Resolução do CONAMA no 357/2005, como sugerido nos estudos de Sousa et al. (2016).

Gráfico 5 - Resultados das análises físico-químicas para a variável potencial de hidrogeniônico (pH) no período úmido (a) (26.10.2018) e (b) (23.11.2018)

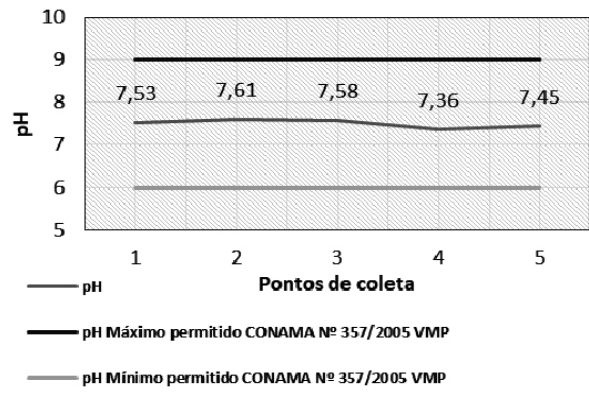

(a)

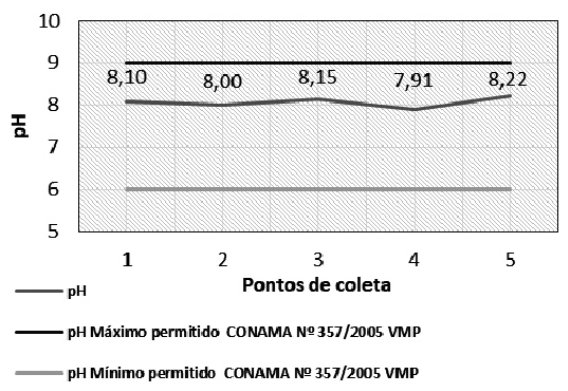

(b)

Fonte: Autores (2019).

A variável cor para o período úmido pode ser verificada no Gráfico 6 (a) e (b). Ambos os resultados dessas análises são respectivamente dos dias 26.10.2018 e 23.11.2018. Os pontos AM-01, localizados nas proximidades das nascentes, apresentaram os menores valores da variável cor com 24,2 (Pt Co)/1 no dia 26.10.2018 e 21,8 (Pt Co)/1 no dia 23.11.2018, quando o regime pluviométrico diário registrado foi, respectivamente, de $10 \mathrm{~mm}$ e $19.6 \mathrm{~mm}$. Os maiores valores foram registrados na AM-03 com 185,0 (Pt Co)/1 para o dia 26.10.2018 e 63,3 para o dia 23.11.2018. Percebe-se no Gráfico 6 (a) que 60\% das amostras estiveram fora dos padrões de qualidade, de acordo com a Resolução do CONAMA nº 357/2005. O uso da água para irrigação, a mudança do uso do solo e a retirada da mata ciliar são fatores que aumentam os processos erosivos e podem contribuir quantitativamente para a inserção de materiais em suspensão no leito do rio nestes pontos; situação essa que pode ser mais intensificada no período chuvoso, como ocorreu em um estudo na bacia hidrográfica do Taquaral, 
em São Mateus do Sul, no Paraná, onde limites de chuva igual ou superior a 25 $\mathrm{mm}$ proporcionaram que $70 \%$ das amostras analisadas obtivessem valores acima do limite permitido pela legislação vigente, de acordo com a classificação à qual o corpo hídrico estava inserido, conforme Luíz, Pinto e Scheffer (2012).

Gráfico 6 - Resultados das análises físico-químicas para a variável cor (Pt Co)/1 no período úmido (a) (26.10.2018) e (b) (23.11.2018)

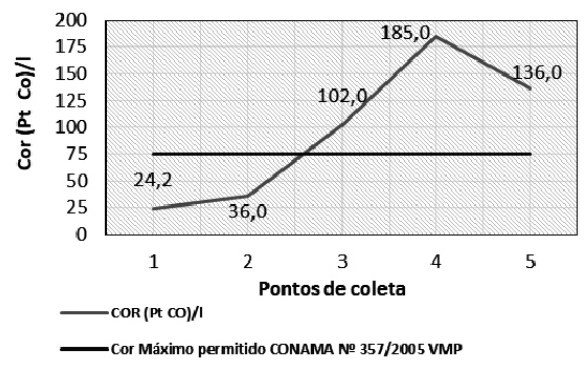

(a)

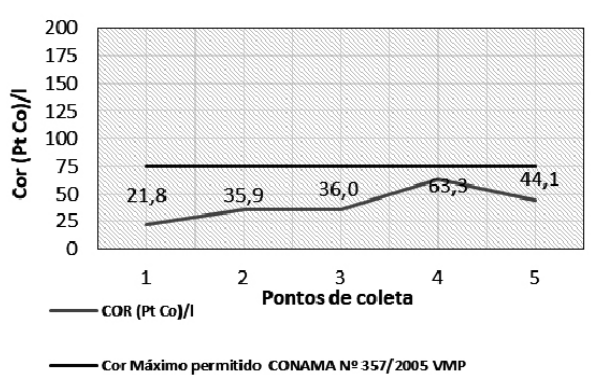

(b)

Fonte: Autores (2019).

A variável turbidez sofre influência de materiais em suspensão, podendo ser ocasionada de maneira natural e/ou antrópica. O Gráfico 7(a) e (b) apresenta o comportamento da turbidez no período úmido, registrando seus valores mais baixos em ambas as fases da coleta no ponto AM-01, os quais ocorreram nos dias 26.10.2018 e 23.11.2018 com seus respectivos valores registrados de 3,5 (NTU) e 2, 23 (NTU). Os índices superiores da turbidez ocorreram no ponto AM-04 em ambas as datas de coleta com os seus respectivos valores de 264,0 (NTU) e 22,90 (NTU). Assim sendo, estes pontos foram classificados como fora dos padrões estabelecidos pela Resolução CONAMA nº 357/2005.

Os pontos AM-03, AM-04 e AM-05 têm alterações geomorfológicas e há presença de processos erosivos devido à supressão da mata ciliar para fins agrícolas, ocasionando em maior lixiviação de sedimentos para o corpo hídrico e prováveis concentrações de materiais sólidos, tendo como consequência maior dispersão do feixe de luz, como o ocorrido no dia 26.10.2018. Situação semelhante foi observada no estudo realizado por Arcova e Cicco (1999), quando encontraram uma variação nos valores de turbidez em período chuvoso devido às diferenças geomorfológicas e hidrográficas da microbacia de Cunha em São Paulo.

Valores semelhantes de alta turbidez estão estritamente correlacionados com os períodos de precipitação e foram encontrados também nos estudos de Chaves et al. (2015), que, em sua análise, destaca que os maiores valores de turbidez encontrados nas águas do rio Piranhas na região do sertão do Rio 
Grande do Norte foram em torno de 44,8 e $166 \mathrm{mg}$ Pt/L, coincidindo com a estação chuvosa daquela região, gerando resultados de uma água com menos penetração de incidência dos raios solares.

O segundo momento (23.11.2018), a coleta apresentou um nível pluviométrico de $19.6 \mathrm{~mm}$ na região, com características de chuvas dispersas não afetando diretamente a área de estudo ocasionando em uma variação da turbidez abaixo de 100 (NTU), aceitável pela legislação vigente.

Gráfico 7 - Resultados das análises físico-químicas para a variável turbidez no período úmido (a) (26.10.2018) e (b) (23.11.2018)

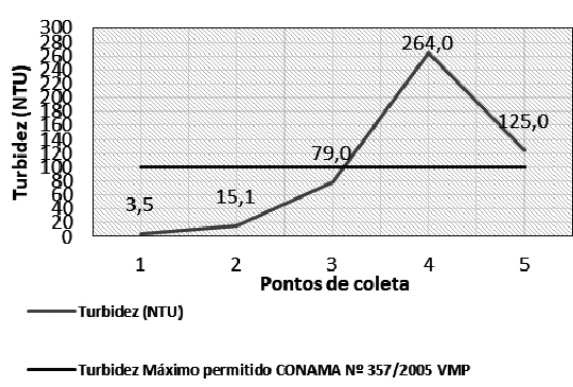

(a)

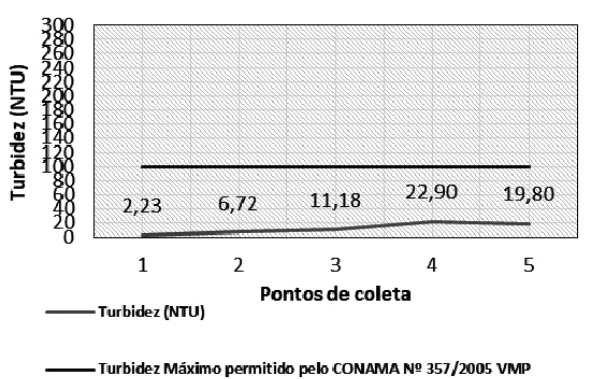

(b)

Fonte: Autores (2019).

Os sólidos totais dissolvidos (STD) para o período úmido observados no Gráfico 8 (a) e (b) mostram que, em ambas as fases das coletas, os resultados estiveram dentro dos limites determinados pela resolução vigente, mantendo-se com concentrações abaixo de 500,0 ppm e ainda mais inferiores que o período seco, discordando de algumas pesquisas que apontam o aumento desse parâmetro como consequência do aumento de STD registrado em todas as localidades no período chuvoso.

Para o dia 26.10.2019 o ponto com menor concentração foi o AM-05 com o valor em 46,0 ppm, já para o dia 26.11.2018 o ponto com maior concentração foi o AM-03 com 82,8 ppm, enquanto que as maiores concentrações para os receptivos dias foram de 83,4 ppm e 115,4 ppm. Embora o período seja o chuvoso, os valores foram relativamente baixos, isso devido à média de precipitação não ter sido o suficiente para propiciar altas concentrações de STD, não acarretando em comprometimento na qualidade das águas do rio Traíras, como consideraram Paula et al. (2013) em um estudo com valores semelhantes realizado no rio Dourados, em Mato Grosso do Sul. 
Gráfico 8 - Resultados das análises físico-químicas para a variável sólidos totais dissolvidos (STD) no período úmido (a) (26.10.2018) e (b) (23.11.2018)

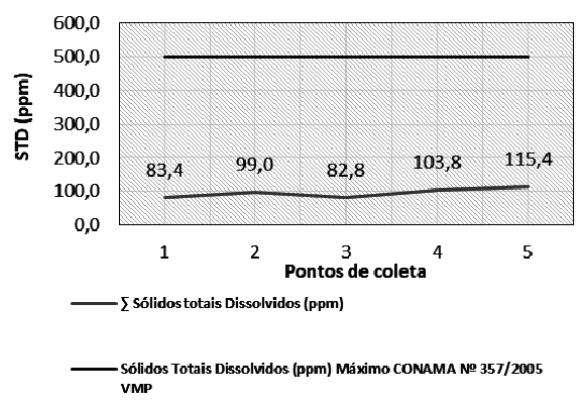

(a)

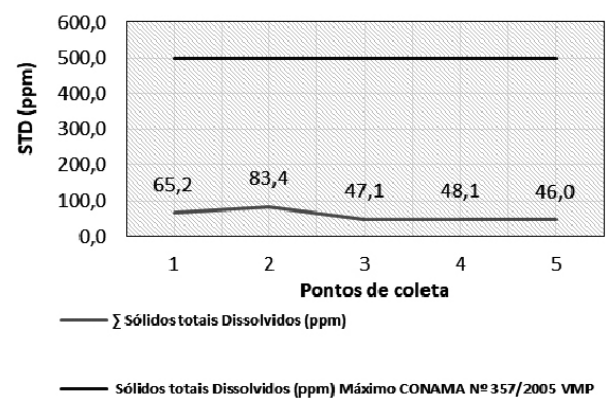

(b)

Fonte: Autores (2019).

\section{CONCLUSÃO}

O rio Traíras tem uma elevada importância para o município niquelandense, pois é a fonte de abastecimento potável da cidade. Nas análises sazonais deste estudo, observou-se que, atualmente, a qualidade ambiental da água se encontra dentro dos parâmetros determinados pela Resolução do CONAMA nº 357/2005 e, consequentemente, própria para o consumo humano.

$\mathrm{O}$ parâmetro $\mathrm{pH}$ foi obtido dentro da média em todos os períodos, tendo apenas um leve aumento no período chuvoso no ponto AM-05. O STD teve comportamento diferente do normalmente apresentado na literatura, com valores superiores no período seco e inferiores no úmido. Tal comportamento pode ser explicado pelo baixo volume de chuvas na região, ocasionando em baixa concentração de sedimentos. Contudo, o valor superior no período seco indica que possíveis atividades degradantes estão alterando significativamente o parâmetro desde a nascente, no ponto AM-01, até o ponto AM-05, nas proximidades da rodovia GO-414. Os parâmetros cor e turbidez nos pontos AM-03, AM04 e AM05 obtiveram alterações significativas quando comparados aos demais pontos amostrais no período chuvoso. Isso em razão da presença das atividades degradantes nas proximidades desse ponto amostral, além da geomorfologia local. A pecuária e a introdução de novas monoculturas nas proximidades da linha de costa do rio provocam alteração na dinâmica natural deste ecossistema, servindo de alerta para novos estudos, o que leva à necessidade de aplicação de um plano de gestão ambiental e de zoneamento ecológico-econômico por parte da reserva LVC para minimização dos possíveis danos ambientais futuros. 
Ainda assim, faz-se necessário um planejamento por parte dos governantes e órgãos fiscalizadores do município de Niquelândia na tentativa de corrigir possíveis danos que afetem a qualidade ambiental da água no futuro, necessitando de uma fiscalização intensificada e da adoção de atitudes preconizadas pela legislação na punição dos casos relapsos.

\section{REFERÊNCIAS}

ANA. Recursos hídricos: resumo executivo. Brasília: MMA; ANA, 2007. 60 p.

ANA. Relatório da ANA apresenta situação das águas do Brasil no contexto de crise hídrica. Agência Nacional de Águas, Brasília, 2017. Disponível em: http:/ / www3.ana.gov.br/portal/ANA/noticias/relatorio-da-ana-apresenta-situacaodas-aguas-do-brasil-no-contexto-de-crise-hidrica. Acesso em: 04 dez. 2018.

ARCOVA, F. C. S.; CICCO, V. Qualidade da água de microbacias com diferentes usos do solo na região de Cunha, estado de São Paulo. Scientia Forestalis, n. 56, p. 125-134, 1999.

BERTRAN, P. Niquelândia 250 anos. Brasília: Ministério da Cultura; Niquelândia: Prefeitura de Niquelândia, 1985. 23 p.

BERTRAN, P. História de Niquelândia: do distrito de Tocantins ao lago de Serra da Mesa. 2. ed. Brasília: Verano Editora, 1998.

BRASIL. Ministério de Meio Ambiente. Resolução CONAMA No 357, de 17 de março de 2005. Dispõe sobre a classificação dos corpos de água e diretrizes ambientais para o seu enquadramento [...]. Brasília, DF: MMA, [2005]. Disponível em: http://www.mma.gov.br/port/conama/res/res05/res35705. pdf. Acesso em: 12 set. 2019.

BRASIL. Ministério de Meio Ambiente. Caderno da Região Hidrográfica do Tocantins-Araguaia. Brasília: MMA, 2006a. 132 p.

BRASIL. Ministério do Meio Ambiente. Caderno setorial de recursos hídricos: agropecuária/Ministério do Meio Ambiente, Secretaria de Recursos Hídricos. Brasília: MMA, 2006b.

BROD, J. A.; JOST, H. Características estruturais, litológicas e magmáticas da zona de cisalhamento dúctil do rio Traíras, bloco do complexo Niquelândia, Goiás. Revista Brasileira de Geociências, Brasília, v. 21, n. 3, p. 205-217, 1991. CHAVES, A. Dél C. G. et al. Monitoramento e qualidade das águas do Rio Piranhas. Revista Verde de Agroecologia e Desenvolvimento Sustentável, Pombal, v. 10, n. 1, p. 160-164, jan./mar., 2015. 
CORREIA, A.; BARROS, E.; SILVA, J.; RAMALHO, J. Análise da turbidez da água em diferentes estados de tratamento. In: ENCONTRO REGIONAL DE MATEMÁTICA APLICADA E COMPUTACIONAL, 8., Natal. Anais [...]. Natal: UFRN, 2008. p. 1-5. Disponível em: http://www.dimap.ufrn.br/ sbmac/ ermac2008/Anais/Resumos\%20Estendidos/Analise \%20da\%20turbidez_ Aislan\%20Correia.pdf. Acesso em: 16 ago. 2018.

COUTINHO, L. M. Biomas Brasileiros. São Paulo: Oficina de Textos, 2016.

CUNHA, D. G. F . et al. Resolução CONAMA 357/2005: análise espacial e temporal de não conformidades em rios e reservatórios do estado de São Paulo de acordo com seus enquadramentos (2005-2009). Engenharia Sanitária e Ambiental, [S. l.], v. 18, n. 2, p. 159-168, abr./jun. 2013.

ESTEVES, F. A. Fundamentos de Limnologia. Rio de Janeiro: Interciência, 1998. $602 \mathrm{p}$.

GOIÁS. Secretaria de Indústria e Comércio/Superintendência de Geologia e Mineração. Hidrogeologia do Estado de Goiás. Goiânia: Secretaria de Indústria e Comércio; Superintendência de Geologia e Mineração, 2006.

IBGE. Cidades: Niquelândia. IBGE, Rio de Janeiro, 2018. Disponível em: http://www.cidades.ibge.gov.br/xtras/perfil.php?lang=\&codmun=521460\&sea rch=| | infogra ficos:informações-completas. Acesso em: 10 abr. 2018.

IBGE. Água doce do Norte, IBGE, Rio de Janeiro, 2019. Disponível em: https://cidades.ibge.gov.br/brasil/es/agua-doce-do-norte/panoramas. Acesso em: 14 dez. 2019.

INMET. Dados históricos. INMET, Brasília, DF, 2016. Disponível em: http:// www.inmet.gov.br/portal/index.php?r=bdmep/bdmep. Acesso em: 26 mar. 2020. INMET. Estações convencionais, INMET, Brasília, DF, 2019. Disponível em: http://www.inmet.gov.br/portal/index.php?r=estacoes/estacoesConvencio nais. Acesso em: 26 mar. 2020.

LIMA, J. E. F. W. Recursos hídricos no Brasil e no mundo. Planaltina: Embrapa Cerrados, 2001.

LUÍZ, A. M. E.; PINTO, M. L. C.; SCHEFFER, E. W. O. Parâmetros de cor e turbidez como indicadores de impactos resultantes do uso do solo, na bacia hidrográfica do rio Taquaral, São Mateus do Sul-PR. RA'E'GA, Curitiba, v. 24, p. 290-310, 2012. 


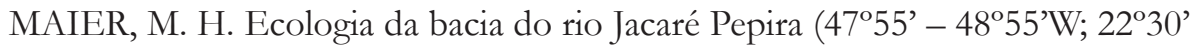

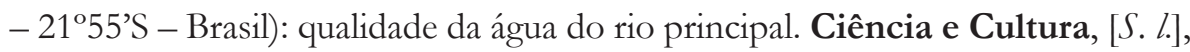
v. 39, n. 2, p. 164-185, 1987.

PARRON, M. L.; MUNIZ, D. H. S.; PEREIRA, C. M. Manual de procedimentos de amostragem e análise físico-química da água. Colombo: Embrapa Florestas, 2011.

PAULA, S. M. et al. Qualidade da água do rio Dourados, MS-para metros físicoquímicos e microbiológicos. Evidencia Interdisciplinar, Joaçaba, v. 13, n. 2, p. 83-100, 2013.

PEREIRA. L. O. Mapeamento do rio Traíras na reserva Legado Verdes do Cerrado no município de Niquelândia, Goiás, Brasil, através do software Quantum GIS-QGIS. 2017. Trabalho de Conclusão de Curso (Graduação em Geografia) - Faculdade de Geografia, Universidade Estadual de Goiás, Goiânia, 2017.

PIRATOBA, A. R. A. et al. Caracterização de parâmetros de qualidade da água na área portuária de Barcarena, PA, Brasil. Ambiente \& Água, [S. l.], v. 12, n. 3, p. 435-456, 2017.

PORTO, M. F. A.; PORTO, R. L. Gestão de bacias hidrográficas. Estudos Avançados, São Paulo, v. 22, n. 63 p. 43-60, 2008.

RODARTE, T. P. et al. Análise descritiva da precipitação, vazão afluente e vazão defluente do lago Serra da Mesa-GO. In: PACHECO, C. S. G. R. (org.). Desafios Socioambientais e proteção do meio ambiente. Petrolina: Kelison Lima Cavalcante, 2018. v. 1. p. 47-55.

SANTOS, H. I.; PAIXÃO, K. V. Gestão de recursos hídricos em Goiás. Goiânia: UEG, 2003.

SCORSAFAVA , M. A. et al. Avaliação físico-química da qualidade de água de poços e minas destinada ao consumo humano. Rev. Inst. Adolfo Lutz, São Paulo, v. 69, n. 2, p. 229-232, 2010.

SILVA, J. B. et al. Conflitos sociopolíticos, recursos hídricos e programa um milhão de cisternas na região semiárida da Paraíba. Novos Cadernos NAEA, Belém, v. 18, n. 2, p. 69-92, jun./set. 2015.

SILVA NETO, J. B. et al. Diagnósticos dos recursos hídricos: disponibilidade e demanda para a Região Metropolitana de Goiânia. RENEFARA, Goiânia, v. 8, n. 8, p. 149-167, 2016. 
SILVA, C. M. S.; SILVA, E. J. M.; OLIVEIRA, J. V. C. Avaliação de impacto ambiental das águas do rio Traíras na reserva Legado Verdes do Cerrado (LVC) no município de Niquelândia, Goiás, Brasil. In: FRANCISCO, P. R. M. (org.). Água: desenvolvimento sustentável e compartilhamento. Campina Grande: EPGRAF, 2018. v. 1. p. 65-76.

SOUSA, S. S. et al. Análise físico-química e microbiológica da água do rio Grajaú, na cidade de Grajaú-MA. Ciência e Natura, v. 38, n. 3, p. 1615-1625, set./dez. 2016.

SOUZA, J. R. et al. A importância da qualidade da água e os seus múltiplos usos: caso Rio Almada, sul da Bahia, Brasil. REDE - Revista Eletrônica do Prodema, Fortaleza, v. 8, n. 1, abr. 2014.

VON SPERLING, M. Introdução à qualidade das águas e ao tratamento de esgotos. 3. ed. Belo Horizonte: UFMG, 2005. v. 1. 452 p. 
